\title{
Teaching and Learning of Peace and Security Studies in Universities: Student's Reflections on Quality and Implications for Curriculum Implementation
}

\author{
Mutendwahothe Walter Lumadi
}

Department of Curriculum and Instruction, College of Education, University of South Africa

Email: Lumadmw@unisa.ac.za

\author{
Doi:10.5901/mjss.2014.v5n15p281
}

\begin{abstract}
Loss of pedagogical momentum (LPM) is used to describe the inability of lecturers to sustain effective teaching throughout a lesson or an entire course, especially in the Peace and Security academic programmes offered in some Kenyan universities. In this study, 152 students from five universities claimed (via questionnaires and interviews) that their lecturers' teaching was characterised by "strong" introductory lessons that gradually became "weaker" as their lessons developed and were finally concluded. In particular, these students were of the view that their lecturers were well able to introduce lessons and specify learning objectives for every lesson, but were unable to summarise lessons and use a variety of teaching methods. The students' further appealed for more heuristic-oriented strategies, such as field trips, simulations and practical training to replace an over-exposure to theory, a situation which further suggested that that the teaching methodology in the programme is overburdened by strategies that are based on exposition. However, it appears that LPM is a by-product of the failure of Kenyan universities to allocate the resources and facilities that are needed to permit the effective teaching and learning of Peace and Security Studies. Although this study recommends the allocation of adequate resources, enhancement of practical training and in-house training of lecturers in the appropriate methodology, it remains to be seen whether the current scenario will continue to facilitate the peace and security objectives of Kenya's Vision 2030 and thus maintain Kenya's position as East Africa's intellectual hub as far as Peace and Security Studies are concerned.
\end{abstract}

\section{Introduction}

The quest for quality Peace and Security education in Kenya has been prioritised in the country's Vision 2030, which outlines intensified training of security staff as one of the key strategies to the creation of a more secure Kenya (Republic of Kenya, 2008; Bonn International Centre for Conversion-BICC, 2005; Kenya Police, 2004: 24). Furthermore, the position of Kenya as an regional intellectual and economic powerhouse in East Africa, with six of her universities among the top 100 in Africa (Webometrics, 2013; African Development Bank, 2008), equally demands that the country play a key role in regional peace and security by training peace and security professionals to ensure that her neighbours continue to enjoy stability. These issues have consequently ignited discourses regarding the quality of the Peace and Security academic programmes offered, especially the capacity of academic staff in Kenyan universities to deliver quality teaching and learning services (Gudo, Oanda \& Olel, 2011b, Asembo, 2008; Kinyanjui, 2007). The concerns are categorical, given the recent "explosion" in the demand for university education in Kenya and the fact that few Kenyan universities have, until now, offered Peace and Security academic programmes (Gudo, Oanda \& Olel, 2011b, Kinyanjui, 2007). More precisely, Kairu (2011), in her article entitled "The fall and fall of university education standards in Kenya", has decried the deteriorating education standards in Kenyan universities.

Cheserek (2010) explains that the concept of quality teaching and learning implies adding value to education and training programmes and to meeting students' expectations as consumers of educational services. The process begins with formulating student learning outcomes and ends with the realisation of these outcomes when the student graduates. The role of the lecturer is to facilitate the realisation of these outcomes by teaching relevant content, and by encouraging learners' active engagement with the learning process and the real world (Domizio, 2008; Hill et al, 2003, Pennington \& O'Neil, 1994). This process therefore requires a highly competent lecturer, whose mastery of content, enthusiasm and affective skills are nothing short of outstanding. However, Mengo (2011) emphasises the fact that, against this argument, quality teaching and learning cannot be guaranteed, given the escalating student population of Kenyan universities and the fact that teaching staff have little time to research, attend conferences and give students their full attention. It is within this framework that this study sets out to determine students' perception of the quality of teaching and learning methodology in the Peace and Security academic programmes offered in Kenyan universities. 


\section{Literature Review}

Defining quality teaching and learning in Higher Education (HE) is an inherently contentious issue and there is little consensus about what characterises effective teaching, given the various disputes about what the aims of $\mathrm{HE}$ should be (Allan, Clarke \& Jopling, 2009). Similarly, Mohanan (2005) has profiled a university graduate as someone who possesses the knowledge, abilities and attitudes necessary to function effectively in familiar and novel situations in his or her personal, intellectual and professional life. The author outlines seven key values which the graduate needs to acquire in order to function effectively. These are knowledge, application, critical thinking, independent learning, articulateness, mind-set and values, as well as good interpersonal skills. Bringing out all these qualities in the university graduate is the hallmark of quality teaching.

Hamid and Zaidatol (2004) recognise the role of academic staff in university teaching and emphasise the fact that customer satisfaction in HE cannot be divorced from the teacher. This is because the quality of the teaching staff is one of the expectations that students have when they enter a university. In Lammers and Murphy's study (2002), it was concluded that lecturers' enthusiasm, knowledge of the subject, and effective classroom management are highly valued skills that interact with other factors (e.g. course design) to produce effective teaching and learning. Similarly, MortonCooper (1993) in a research study on lecturer traits valued by students cited reliability and consistency as the major traits. Other scholars such as Domizio, (2008), Hill et al. (2003) and Pennington and O'Neil (1994) have also cited lecturer enthusiasm as a vital trait that encourages effective learning.

Hamid and Zaidatol (2004) agree that the measure of quality teaching and learning needs to focus on the dimensional factors that directly influence the process delivery of instructional design and course outcomes. Similarly, Entwistle and Ramsden (1987) note that quality teaching and learning in the university is that which engages the student in an in-depth and comprehensive approach to the subject matter, that is, in an active, durable, and critical construction of knowledge that is integrated with his or her previous knowledge and then appropriately applied. Given this fact, Pennington and O'Neil (1994) proposed eight principles that underscore effective teaching. These are: (1) enhancing students' general capabilities and work-related skills; (2) using student experience as a learning resource; (3) encouraging active and co-operative learning; (4) promoting responsibility in learning; (5) engaging with feelings, values and motives as well as with intellectual development; (6) fostering open, flexible, reflexive and outcome - based assessment; (7) evaluating teaching and learning to encourage reflective teaching; and (8) developing organisational strategies to establish policies that are congruent and that enhance the physical and material learning environment.

Hill, Lomas and MacGregor (2003) equally found that students' perceptions of quality learning included experiences that helped them to link theory with the real world. This included assignments that are relevant to the real workplace, discussions leading to new perspectives of thinking, and a curriculum that took account of the students' group experiences and imparted added value to students. Hill also reported the emergence of three major teaching strategies which were highly rated by students in HE: delivery strategy and techniques in the classroom; feedback to students in the classroom and in assignments; and relationship with students in the classroom.

Perrenoud (1999), as quoted in UNESCO (2004), has described the following ten attributes of a good teacher: (1) organising student learning opportunities; (2) managing student learning progression; (3) dealing with student heterogeneity; (4) developing student commitment to working and learning; (5) working in teams; (6) participating in school curriculum and organisation development; (7) promoting parent and community commitment to school; (8) using new technologies in their daily practice; (9) tackling professional duties and ethical dilemmas; and (10) managing their own professional development.

Even though there seems to be lack of consensus on the nature and number of dimensions that represent quality teaching and learning in $\mathrm{HE}$, there appears to be some agreement on what constitutes the generic features of effective teaching. Hopkins et al (1997), as quoted in Allan, Clarke and Jopling (2009), have outlined three dimensions of quality teaching. The first is teaching effects, which includes both teaching skills and teaching behaviours. The second is the acquisition of quality teaching and learning models, which describes particular types of learning environments that a teacher establishes in his/her classroom. The third dimension is teacher enthusiasm, which emphasises personal responsibility for creating the conditions for effective learning.

After a review of various research studies undertaken over a period of 30 years, Allan, Clarke and Jopling (2009) equally propose the need for a supportive learning environment, along with scaffolding learning, academic expectations and clarity as key indicators of quality teaching. The authors explain that a supportive learning environment includes that which provides an intellectually exciting, stimulating and creative environment; has a high degree of subject knowledge; recognises student diversity; and is motivating and is based on a climate of approachability. Academic expectations are characterised by expected outcomes expressed directly in academic terms. These expectations include a high level of 
expected output; a clear statement of objectives; clarity in evaluation and assessment procedures; manageable workloads; and critical thinking. Similarly, scaffolding learning consists of the dynamics of content delivery; anticipation of misconceptions in students' existing knowledge; pace setting for learners; high engagement levels; excellent classroom management; systematic organisation of learning; team work; immediate feedback; encouragement of independent learning; encouragement of active learning; and effective and sympathetic guidance. Clarity includes strong, clear presentation skills and high quality explanations.

Jenkins (2013), while underlining Reardon's (1988) 'transformative imperative' in the implementation of Peace Education programmes, advocates for a transformative peace learning methodology with a focus on generating knowledge that will empower the learner to engage in social reconstruction. The teaching methodology which they endorse is to adopt a holistic approach in presentation of content, but with bias towards social reconstruction and the formation of desirable human relationships. This would empower learners to pursue a variety of social transformations, be these transformations socio-economic, political, personal, or environmental. This idea is equally captured in Danesh's (2008) study of Education for Peace (EFP), which is part of an integrative curriculum in Bosnia and Herzegovina. The author advocates that the curriculum encourage the students to develop worldviews that are essentially based on unity. The key aspects of this curriculum include critical inquiry (which involves freeing the mind by interacting with liberal discourse); emotional insight (which involves invoking affective skills in order to achieve peace); and imaginative and creative experience (which involves transformation of theory into practical peaceful actions). While critical inquiry can be achieved through theoretical discourses delivered through lectures, emotional insights and imaginative and creative experiences demand training that is practical in nature.

Moreover, in a study of the teaching and learning of an International Baccalaureate (IB) diploma in a Peace and Conflict studies programme, Van Oord (2008) underscores the vitality of student-oriented pedagogical strategies, where discussions by students are more preferred to lecturing and where experiential learning substitutes the study of huge amounts of content. The author agrees with Bar-Tal (2002) that the transformative goal of effective peace education depends more on the role of the teacher as a facilitator of learning. Similarly, Spracher's (2010) study has equally accentuated the need for a transformative teaching methodology that would realign the conservative orientation of the security sector towards a more pragmatic approach to handling security issues.

Although the strengths of these studies is in defining the basic constituents of quality teaching and learning in $\mathrm{HE}$, no known study has explored student's perceptions of the quality of teaching and learning methodology in the Peace and Security Studies in universities in Kenya, hence this article.

\section{Theoretical Framework}

The theoretical framework of this study is based on two theories: humanistic and social reconstructionist conceptions of the curriculum and the theory of service quality.

\subsection{Humanistic and social reconstructionist conceptions of the curriculum}

These conceptions of the curriculum offer insight into understanding the orientations which inform the design and delivery of quality teaching and learning in Peace and Security Studies. The humanistic curriculum is centred on the development of the individual by helping him or her discover his or her real self as opposed to being shaped into a predetermined model

(McNeil, 1996). The ultimate goal is self-actualisation, and a self-actualised person will be both aesthetically and morally healthy. Attempting to achieve this goal implies 'learners being permitted to express, act out, experiment, make mistakes, be seen, get feedback and discover who they are' (McNeil, 1996:7). The key concern is on participation, integration, relevance, self and comprehensive student experience rather than the acquisition of fragmented blocks of knowledge (Shapiro, 1987). The role of the lecturer in delivering this curriculum is to establish an emotional relationship with the students and create a supportive teaching and learning environment that will encourage the learner to learn independently. The lecturer also listens comprehensively to student's views, respects the student, remains ordinary and real, understands, facilitates, and acts as resource centre. Other approaches include encounter groups, meditation, game-like activities, and small group discussions (McNeil, 1996:9-11; Print, 1993: 51-2.

The social reconstructionist curriculum, on the other hand, emphasises the relationship between the curriculum and the social, political and economic development of society (Print, 1993; McNeil, 1996). Social reconstructionists see the goals of a curriculum as determination of the range of problems faced by a society, and developing key approaches that will bring about the desired change to that society (Freire, 1970; Eisner, 1979; McNeil, 1996). The emphasis on this 
type of curriculum is on confronting the learner with the many serious problems which humanity faces be they in social studies, sciences, arts or maths, and then imparting knowledge that will help the learners to solve these problems. The role of the lecturer in delivering this curriculum is to invoke the student's critical consciousness and make learning more liberal, while relating the subject matter to the student's goals. The lecturer is still expected to adopt heuristic strategies, which involve emphasising student cooperation with the community and its resources, as well as seeking internship opportunities for learners to work as equals with more experienced members of the community in social projects.

The relevance of humanistic and social reconstructionist theories, as far as this study is concerned, is to present Peace and Security Studies in HE as humanistic and problem-solving subject areas, whose mode of delivery be based on a similar orientation. These modes not only embrace the creation of a supportive learning environment (as underscored by Allan, Clarke and Jopling (2009)), but also enhance students' general capabilities and work-related skills and encourage active and cooperative learning (Pennington \& O'Neil, 1994).

\subsection{Service quality}

Service delivery has become a major component of customer satisfaction and profitability, and is therefore a key in ensuring that a company has a competitive advantage in the business world. Scholars agree that what truly adds value to the customer is not so much what is delivered, but how it is delivered (Kandampully \& Kandampully, 2006; Van Schalkwyk, 2011). In pedagogy, "service' means methodology. The two key traits of any service is that it is intangible and inseparable from what is produced and consumed (Van Schalkwyk, 2011). This is why Wilson et al (2008:6) define services as "all economic activities whose output is not a physical product or construction, is generally consumed at the time it is produced, and provides added value in forms (such as convenience, amusement, comfort or health) that are essentially intangible concerns of its first purchaser".

Quality, on the other hand, has been defined in a variety of ways. Whereas a number of quality specialists refer to quality as everything that leads to customer satisfaction, other specialists refer to it as a total absence of defects or the level of superiority or excellence attached to a product or service (Van Schalkwyk, 2011; Ramphal, 2011). At the centre of quality effort is the desire to meet or exceed customer expectations. In a study aimed at defining quality, Evans (2011) found that many managers perceive a quality service or product as that which is perfect, reliable, economical, timely, conforming to specifications, efficient, impressive, delightful, and provides wholesome customer service and satisfaction.

Mishra (2006), on the other hand, regards quality as "software" and emphasises correctness, reliability, efficiency, integrity, usability, maintainability, testability, expandability, portability, reusability and interoperability as characteristics of consistent software products. Owlia and Aspinwall (1996) have transferred these software quality dimensions to HE and propose the following as applicable to HE: correctness refers to the extent to which a programme complies with the specific requirement; reliability refers to the degree to which knowledge and skills learned are correct, accurate and up to date; efficiency implies the extent to which knowledge and skills learned are applicable to the future career of graduates; integrity is the extent to which personal information is secure from unauthorised access; usability refers to the ease of learning and degree of communicativeness in the classroom; maintainability refers how well an institution handles customers' complaints; testability implies the fairness of examination in relation to the subject of study; expandability refers to flexibility of the educational programmes; while portability, usability, and interoperability refer to the degree to which knowledge and skills learned can be applied to other fields.

In another study, Chua (2004) explains that students are actually consumers purchasing the services provided by education; students therefore have the right to obtain the best quality education. This is why a university should regard its students as its primary customers, customers who receive the university's educational services (Madu \& Kuei, 1993). Delivery of quality teaching and learning to these customers is therefore of paramount importance and implies understanding their needs and, specifically, the quality attributes these needs imply. The basis of the service quality theory in this study is to diagnose the pedagogical dimensions of quality teaching and learning, which form the basis of student satisfaction in an instructional activity. On the basis of service quality theory, such dimensions would include pedagogical activities which are tangible, reliable, responsive, competent, courteous, communicative, credible, secure, understandable, efficient, honest, usable, testable, expandable, portable and interoperable.

\section{Methodology}

The study was a descriptive survey that was carried out within the framework of a positivist-interpretivist research paradigm. Data was collected through random sampling via questionnaires and interviews from a total of 152 finalist and pre-finalist students who were in the process of studying for diploma and undergraduate courses in Peace and Security 
academic programmes in five universities in Kenya (one private and four public). The questionnaire was a modified Service Performance (SERVPERF) instrument using a five-point Likert rating scale. This scale is scored as follows: 5 strongly agree; 4 - agree, 3 - somewhat agree; 2 - disagree, and 1 - strongly disagree. The interviews involved both Focused Group Discussions (FGDs) and in-depth interviews. The data was analysed both qualitatively (by coding into themes and categories) and quantitatively (by the use of Statistical Package for Social Sciences (SPSS) Version 17.0).

During analysis, the data was re-coded into a three-point scoring scale with points 5 and 4 combined and re-coded to denote 'higher agreement'; point 3 recoded to denote 'moderate agreement' while points 1 and 2 were combined and re-coded to denote 'lower agreement' . Hamid and Zaidatol (2004: 73-4) agree that this kind of re-coding into a threepoint scale allows a 'more distinct focus' for the interpretation of data. The quantitative analysis involved the calculation of frequencies, percentages, mean scores and standard deviations. While presenting the data in tables, the variables were itemised and ranked chronologically by mean scores.

\section{Findings and Discussion}

Students' perceptions of the quality of teaching and learning methodology were measured using one construct: lecturer teaching competence. Competence in this case refers to the ability of the lecturer to deliver the lesson effectively. It includes the service quality dimension of responsiveness, and the ability to perform the promised service dependably and accurately (Parasuraman, Zeithaml \& Berry, 1990). This construct contained 13 attributes that focused on lesson introduction: specification of learning objectives; use of suitable examples and illustrations; tasks and assignments, questioning technique; pace of instruction; transitions within lessons; summaries; lesson presentation; stimulation of thinking; handling of questions; and use of a variety of techniques. The findings are presented in Table 1:

Table 1: Students' perceptions of quality of teaching and learning methodology in HE in Peace and Security Studies in Kenyan universities

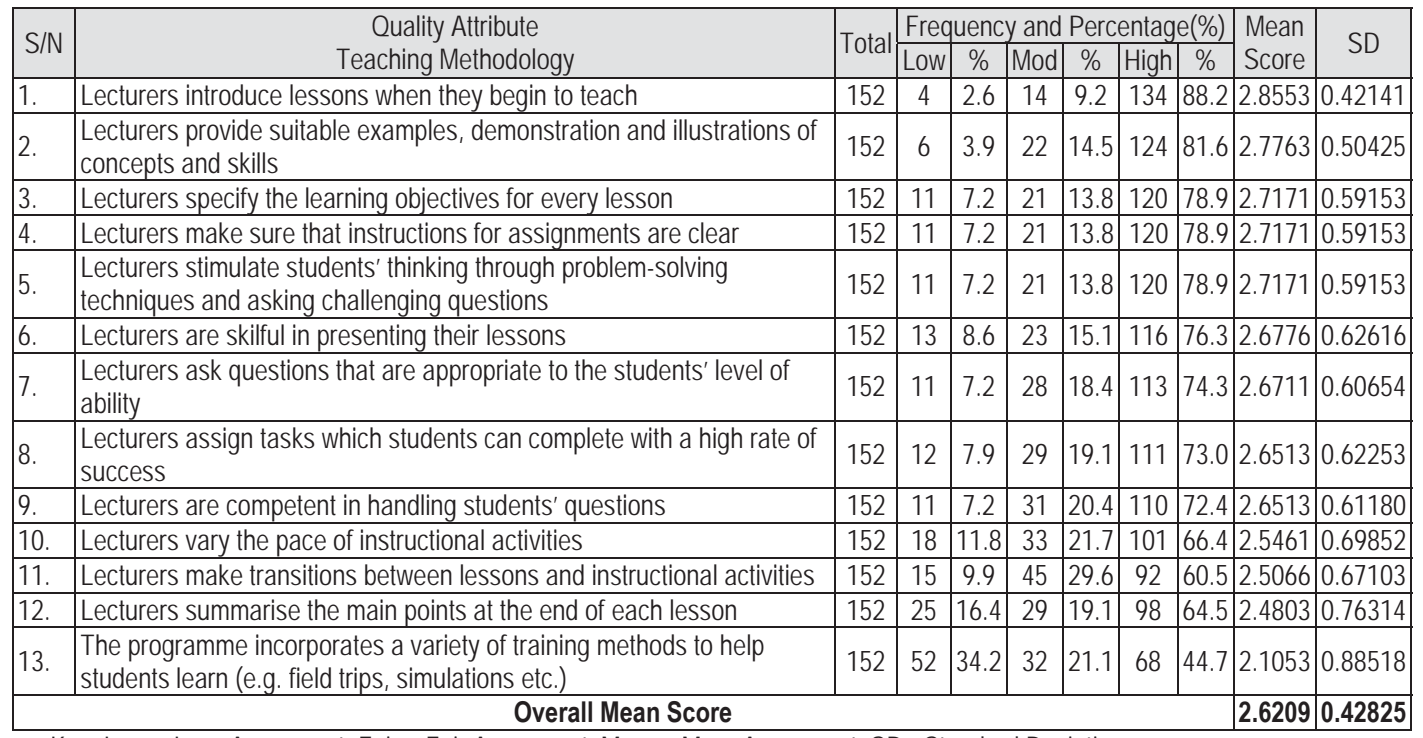

Key: Less= Less Agreement; Fair = Fair Agreement; More = More Agreement; SD= Standard Deviation

The table shows that, even though students perceive lecturers' teaching competence as being high, and characterised by strong introductory content and skills (as indicated in items 1-5: mean scores $=2.8553,2.7763,2.7171,2.7171$, and 2.7171, respectively), they still perceive teaching effectiveness as gradually diminishing as the lessons are developed. The latter is indicated in items 6-10 (mean scores $=2.6776,2.6711,2.6513,2.6513,2.5461$ and 2.5066). These mean scores suggest a less cohesive teaching methodology in terms of integration of learning and sustaining students' interest and motivation during lesson delivery. The mean scores are, however, much lower for items 12 and 13 (mean scores = 2.4803 and 2.1053), which focus on lesson summary and use of variety of teaching methods. The scores further suggest 
a less satisfying mode of lesson technique and a monocentric heuristic teaching strategy. In this study, this scenario is described as 'Loss of Pedagogical Momentum' (LPM), which implies that the lecturers at these universities are unable to sustain effective teaching throughout their lessons or the course as a whole.

The data presents a scenario where lecturers begin teaching with passion but gradually lose interest as the lesson proceeds; this, in turn, leads to weak lessons and weak courses. From the three dimensions of quality teaching underlined by Hopkins et al (1997), it appears that the lecturers are able to demonstrate effective quality teaching and learning models through establishment of motivating learning environments at the beginning of their lessons ( items 1,2,3 \& 5), but they lose out on the teaching effects, (item 6, 7, 9, 10 \& 11) and they also lose out on teacher enthusiasm (items $8,12 \& 13$ ). This explains the overall mean score of 2.6209 (SD of 0.42825 ), which suggests that students perceive the quality of teaching and learning methodology, in Peace and Security Studies, as being only moderate.

Data collected from the interviews indicates that students decry the over-reliance on the lecture method and delivery of theoretical knowledge as the main teaching strategy. Students called for the inclusion of the practical aspect of teaching, coupled with field trips, where necessary, in order to reduce classroom boredom. Anungo Kibaw, a degree student of disaster management, noted as follows:

The lectures are well delivered. However, the majority of the lecturers rely on the lecture method alone, with some discussion. Field trips should be included in our studies as we have had enough of theory. noted:

Ogejo Janam equally emphasised the need for various teaching learning methods in criminal justice. This student

More field trips and simulations should be made available to the students of criminal justice, in order for them to be able to experience the actual reality of criminal justice systems rather than peripheral exposure to what the ideal situation should be.

Another student, Aoko Nyobonyo, a degree student of Forensic Investigations, who is also a high school teacher in Nairobi, made the following statement:

There is a need to include other teaching and learning techniques, especially in areas that need practical approach and real life experiences, such as management of scenes of crime. There is also a need for the lecturers to know that we are not just in class for promotion but to develop our careers as future professionals, hence the need for a more robust approach to teaching. The university should establish a forensic laboratory.

Okombe Nyadero, another student of Criminology, decried the consequences of lack of practical training, on their future lives as job seekers:

On the practical side of this course, nothing takes place. We only do the theories and class work and nothing else. This will make it hard for those students to get jobs and it may force then to enrol in other institutions to do the practical part which was left out.

The overall implication of both the qualitative and quantitative data is that students have a low opinion of the teaching and learning methodology used in Kenyan universities. They perceive teaching as characterised by simply the delivery of theoretical content, and an over-reliance on expository strategies, thereby leading to LPM.

LPM could also be attributed to the lack of adequate teaching and learning facilities. The qualitative data indicated that forensic students need a laboratory for their studies. This suggests that the pedagogical scenario examined here is typified by a scarcity of resources which, in turn, forces lecturers to rely on expository strategies and emphasise the theoretical aspects of their discipline. This means that the teaching and learning methodology is necessarily incomplete, a situation that is disadvantageous as far as the provision of quality education is concerned, and the objectives of university education in Kenya.

Pennington and O'Neil (1994) emphasise that effective teaching and learning are not based on simply the encouragement of active and cooperative learning alone, as characterised by the strong introductory content and skills referred to in this study, but also on developing organisational strategies and policies that will improve the physical and material aspects of a learning environment. The absence of a forensic laboratory and the lack of field excursions and simulations or role-plays (in forensic and criminal justice classes) are a reflection of the key challenges facing the pedagogy of Peace and Security Studies in Kenyan universities; this in itself could well lead to LPM. This lack also makes it difficult to achieve the key aims of university education in Kenya, which includes bridging the gap between theory and 
practice in various disciplines of education and training, and imparting hands-on skills (Republic of Kenya, 2006b). It also implies that students will be unable to achieve the general educational aims of autonomy, the ability to participate in reasoned discourse, critical self- evaluation, and will lack a proper awareness of the ultimate contingency of all thought and action (Barnett, 1992).

\section{Conclusions}

The study concludes that the LPM y the academic staff in the teaching and learning of Peace and Security Studies in Kenyan universities undermines the delivery of quality pedagogy. It subjects students to an incomprehensive teaching methodology, one that is characterised by an over-reliance on expository oriented strategies, which are ineffective in the realisation of the humanistic and transformative goals of any Peace and Security Studies curriculum. It further undermines the achievement of Kenya's peace and security objectives in its Vision 2030 and the country's position as East Africa's intellectual powerhouse for regional prosperity. This scenario is a by-product of the failure of Kenyan universities to allocate adequate teaching and learning resources to their Peace and Security Studies curriculum.

\section{Recommendations}

Our recommendations are as follows:

- Kenyan universities need to mobilise their resources to improve the quality of the teaching and learning facilities in order to deliver effective Peace and Security academic programmes.

- Kenyan universities need to intensify practical training in Peace and Security Studies by establishing appropriate laboratories and mainstreaming field excursions, internships and experiential learning as integral components of these programmes.

- Kenyan universities need to organise in-service courses to attune lecturers to more heuristic pedagogical skills in HE in Peace and Security Studies. Examples here are simulation, field excursion, laboratory practical and problem-solving scenarios.

\section{References}

Allan J., K. Clarke and M. Jopling (2009). Effective Teaching in Higher Education: Perceptions of First Year Undergraduate Students. International Journal of Teaching and Learning in Higher Education 2009, Volume 21 Number 3, 362-372. URL: http://www.isetl.org/ijthe/ ISSN 1812-9129. Retrieved on 16 October 2011.

African Development Bank (2008). Kenya 2008-2012 Country Strategy Paper. Nairobi. African Development Bank Country and Regional Department - East A (OREA)

Asembo, K.O. (2008). Higher Education and Police Reforms in Kenya: Prospects and Impediments: Paper presented at Egerton University, Laikipia College Campus Faculty Seminar Series on Monday 7 April, 2008.

Barnett, R. (1992). Improving Higher Education: Total Quality Care, Buckingham: SRHE and OU.

Bonn International Center for Conversion, BICC (2005). Security Sector Reform in Kenya: Inventory of security sector reform (SSR) efforts in partner countries of German development assistance, Bonn International Center for Conversion, Bonn. Available online at: http://www.bicc.de/ssr_gtz/pdf/kenya.pdf. Retrieved on 19 November 2011

Cheserek G. J. (2010). Quality Management in Curriculum Development and Delivery in African universities: A Case Study of Moi University, Kenya. Eldoret: Moi University.

Chua, C. (2004). Perception of Quality in Higher Education. Proceedings of the Australian Universities Quality Forum 2004, Australian Universities Quality Association, Occasional Publication

Danesh, H. B. (2008). "The Education for Peace Integrative Curriculum: Contents, Concepts, and Efficacy." Journal of Peace Education 5 (2): 157-174.

Domizio, P. (2008). Giving a Good Lecture. Diagnostic Histopathology 14:6, 284-288

Eisner, E. (1979). The Educational Imagination: On the design and evaluation of school programs. New York: Macmillan.

Entwistle, N. and Ramsden P. (1987). Understanding Student Learning. London: Croonhelm.

Freire P. (1970). Pedagogy of the Oppressed. New York: Herder and Herder

Hamid J. A. and Zaidatol A. P. (2004). Students' Perception of the Quality of Teaching and Learning in Business Studies Programs. Pertanika Journal of Social Sciences and Humanities 12(1): 71-86 (2004) .

Hill, Y, I. Lomas and J. MacGregor (2003). Students' perceptions of quality in higher education. Quality Assurance in Education 11(1): 15-20.

Hopkins, D., Ainscow, M., West, M., Harris, A., and Beresford, J. (1997). Creating the conditions for classroom improvement. London, David Fulton. Available online at: http://www.cdtl.nus.edu.sg/publications/assess/def. Retrieved on 15.10.2011.

Jenkins, T. (2013). The transformative imperative: the National Peace Academy as an emergent framework for comprehensive peace 
education, Journal of Peace Education, 10:2, 172-196.

Kairu, P. (2011). The fall and fall of University education standards in Kenya. Daily Nation, Wednesday November 9, 2011.

Kandampully, J. \& Kandampully, R. (2006). Service system: a strategic approach to innovate and manage service superiority. in Managing tourism and hospitality services: theory and international applications, edited by B. Prideaux, G. Moscardo \& E. Laws Wallingford, UK: CAB International

Kinyanjui K. (2007). The Transformation of higher education in Kenya: Challenges and opportunities: Paper presented at the 'Mijadala on social policy, governance and development in Kenya' sponsored by development policy management forum on 9 July, 2007 at Nairobi Safari Club.

Lammers, W. and Murphy J. (2002). A profile of teaching techniques used in the University classroom. Active Learning in Higher Education 3(1): 54-67.

Madu, C. N., and Kuei C. H (1993). Dimensions of quality teaching in higher institutions. Total Quality Management, 4(3), 325-338

McNeil, J. (1996). Curriculum: A Comprehensive Introduction ( Fifth Edition ). Los Angeles. HarperCollins College Publishers.

Mishra, S (2006). Quality Assurance in Higher Education. An Introduction: Bangalore: National Assessment and Accreditation Council.

Owlia, M. S. and Aspinwall , E. M (1996). A framework for the dimensions of quality in Higher education. Quality Assurance in Education 4 (2), 12-20.

Parasuraman, A., Zeithaml, V. and Berry, L.L (1990). Delivering Quality Service: Balancing Customer Perceptions and Expectations. New York. The Free Press.

Pennington, G. and M. O'Neil. (1994). Enhancing the quality of teaching and learning in higher education. Quality Assurance in Education 2(3):13-18.

Print, M. (1993). Curriculum Development and Design. St. Leonards, NSW Australia, Allen and Unwin.

Reardon, B. (1988). Comprehensive peace reflection: Educating for global responsibility. New York: Teachers College Press.

Republic of Kenya (2008). Vision 2030. Nairobi. Government Printer.

Spracher, W (2010). 'Intelligence Education: A broader domain than Intelligence studies'. A Conference Paper adapted from a Doctoral Dissertation entitled 'National Security Intelligence Professional Education: A Map of U.S. Civilian University Programs and Competencies'. Unpublished Dissertation, George Washington University. This paper is part of the Conference Papers under Custody of International Studies Association, US.

UNESCO (2004). Workshop 4: Quality Education and the Key Role of Teachers: Discussion paper: IBE, in collaboration with El and UNESCO This document is currently available from the ICE site : www.ibe.unesco.org. Retrieved on 16. 10. 2011.

Van Schalkwyk R. D (2011). 'The Impact of Leadership Practices on Service Quality in Private Higher Education in South Africa'. Unpublished Master of Commerce Thesis, University of South Africa.

Webometrics, (2013) Ranking Web of World Universities- Africa. Available online at: http://www.webometrics.info/en/africa Wilson, A., Zeithaml, V.A., Bitner, J. \& Gremler, D. (2008). Services marketing. Maidenhead, Berkshire: McGraw-Hill. Webometrics, (2013) Ranking Web of World Universities- Africa. Available online at: http://www.webometrics.info/en/africa 